\title{
Using PLS-SEM and Interpretative Analysis for Testing Questionnaire of The Success of Information Systems Strategic Planning Benefit Realization
}

\author{
Bernadus Gunawan Sudarsono ${ }^{1}$, Aedah Binti Abd Rahman ${ }^{2}$, \\ Manorang Sihotang ${ }^{3}$, Alexius Ulan Bani ${ }^{4}$, Agus Budiyantara ${ }^{5}$, Rouly Doharma ${ }^{6}$ \\ \{gunawanbernadus@ubk.ac.id ${ }^{1}$, Aedah.abdrahman@aeu.edu.my², sihotang.manorang@yahoo.co.id ${ }^{3}$, \\ Alexiusulanbani@ubk.ac.id ${ }^{4}$, agusbudiyantara@kampuswiduri.ac.id ${ }^{5}$, \\ roulydoharma@kampuswiduri.ac.id $\left.{ }^{6}\right\}$
}

Universitas Bung Karno, Jakarta, Indonesia ${ }^{1}$, Asia e University, Selangor, Malaysia ${ }^{2}$, Universitas Pramita Indonesia, Tangerang, Indonesia ${ }^{3}$, Universitas Bung Karno, Jakarta, Indonesia ${ }^{4}$, STMIK Widuri, Jakarta, Indonesia $^{5}$, STMIK Widuri, Jakarta, Indonesia ${ }^{6}$

\begin{abstract}
The purpose of this study was to examine the ISSP (Information System Strategic Planning) questionnaire which was related to the factors that influence the success of ISSP, namely in terms of the realization of benefits, with the college population as an example of data collection. This test was carried out using PLS-SEM and interpretative analysis. PLS-SEM analysis is used to test the validity and reliability statistically of the 41 questions in the questionnaire. These statistical results are then used in interpretive analysis which will produce a justification to be taken into consideration in the better updating of the questionnaire. The results of these two analyzes have identified that 3 of the 41 questions recommended are omitted. The benefits of this study are input for other researchers in practical and methodological terms.
\end{abstract}

Keywords: ISSP questionnaire, PLS-SEM analysis, Interpretative analysis.

\section{Introduction}

Activity updating a questionnaire is a common activity carried out in research based on responsiveness and understanding of the respondents $[1,2]$. Updating the questionnaire was carried out by testing the questionnaire $[1,3]$ which was important as an instrument to increase the sharpness of knowledge of an indicator in the model being tested. Questionnaire testing is done serially, namely by first using PLS-SEM analysis which is useful to assess statistical results which then need to be interpreted with interpretive analysis in order to get important recommendations $[1,4]$ on updating the questions in the questionnaire. The activities of these analyzes may be very familiar to expert researchers, but they are not easy for beginner researchers. Therefore, using serial PLS-SEM analysis then the interpretative analysis may still be expected $[1,2]$. In addition, the interpretative analysis may have been used by researchers in various practical surveys, but the use of the second serial analysis of this data has not been clearly identified in various literature.

In this study aims to test the questionnaire factors that influence the success of ISSP related to the realization of the benefits. The initial research activities carried out were testing questionnaires with PLS-SEM analysis which would produce statistical results which then 
became input into interpretive analysis whose output was in the form of justification in the form of recommendations for consideration in updating the questionnaire. The achievement of this study was guided by two research questions, namely:

SQ1: Does the questionnaire related to the factors that influence ISSP's success from the

realization of benefits have good statistical results from PLS-SEM analysis?

SQ2: Have the statistical results justified the recommendations which are the interpretative results for updating the questionnaire?

The next explanation in this article is described in a number of points, namely a brief explanation of the literature, then an explanation of the models, indicators and questionnaire questions. In addition, it was continued with an explanation of the statistical results of the PLSSEM analysis and also an explanation of the interpretative analysis that produced the justification of recommendations. The last of this article concludes with a conclusion.

\section{Literature Review}

The success of ISSP is shown in the realization of benefits in information system strategic planning $[5,6]$. Studies that discuss the factors that influence the success of ISSP have long been discussed[7-9]. But it is still rare for ISSP research to focus on the realization of benefits. Realization of benefits from ISSP can be in the form of strategy alignment, planning effectiveness, capability for new opportunities, competitive advantage, and increased performance. In this study discussed the benefits realization model of ISSP (ISSPBRM) shown in Figure 1. This model consists of variables that appear in table 1 namely Product Quality, Planning System Quality, Service delivery Quality, culture, facilitator, use, satisfaction, and net benefits. Each variable has an indicator as shown in table 1 . The questionnaire to be tested which appears in table 2 is actually derived from each indicator in each variable in the model.

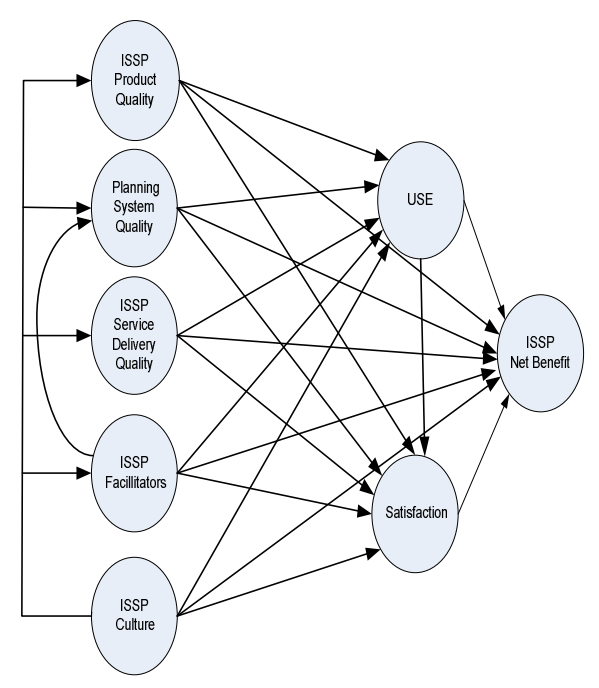

Figure 1. ISSPBRM 
Table 1. Variables and Indicators of ISSPBRM

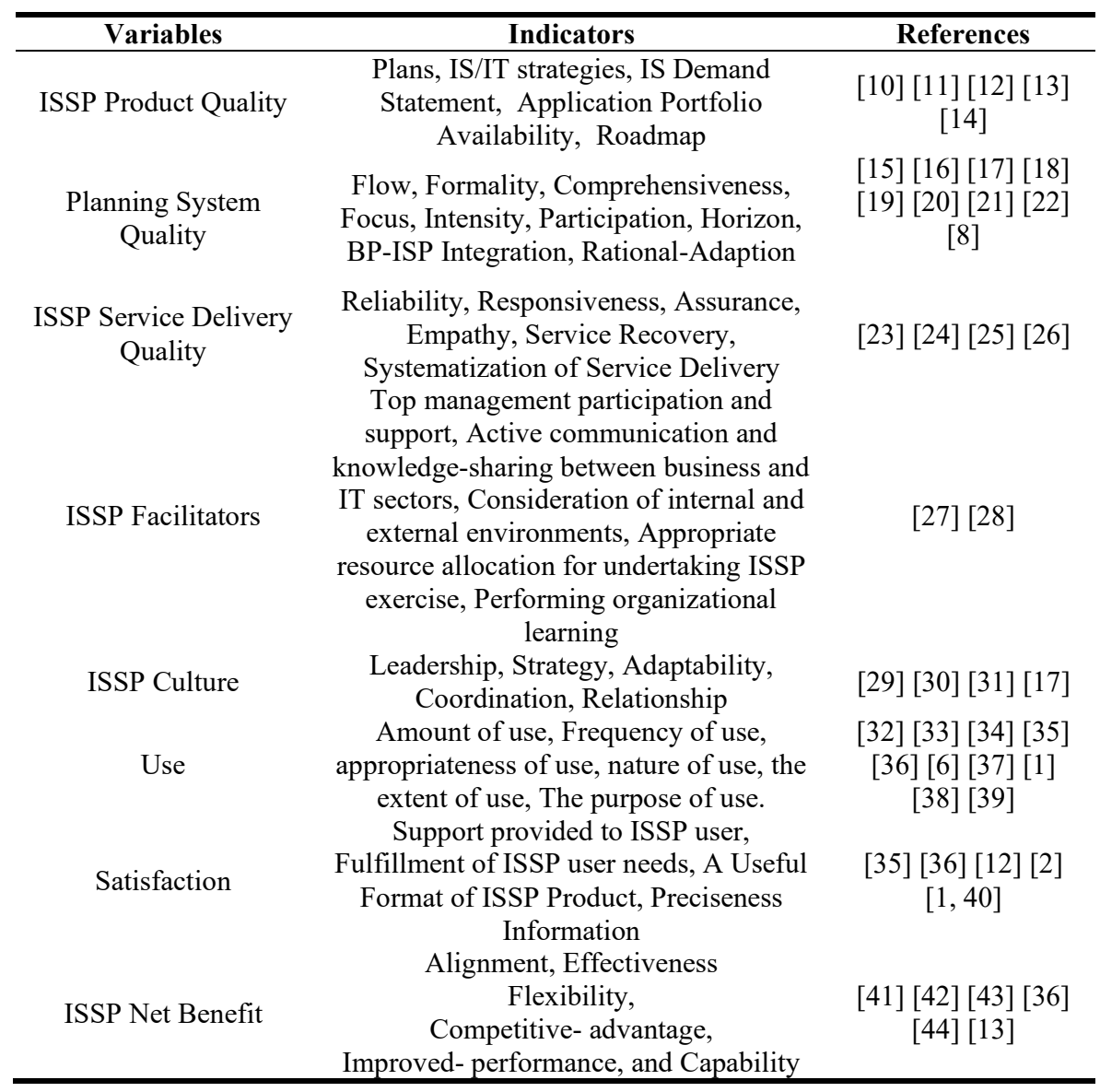

Table 2. Code and Questionnaire

\begin{tabular}{|c|c|}
\hline Code & Questionnaire \\
\hline IPQ1 & Higher Education institutions have information system planning. \\
\hline IPQ2 & $\begin{array}{l}\text { Higher Education institutions have an information system strategy } \\
\text { /information technology strategy. }\end{array}$ \\
\hline IPQ3 & $\begin{array}{l}\text { Higher Education institutions have links with application portfolios (notes on } \\
\text { applications) as ISSP products. }\end{array}$ \\
\hline IPQ4 & $\begin{array}{l}\text { Higher Education institutions have documents about information system } \\
\text { requirements or information technology needs. }\end{array}$ \\
\hline IPQ5 & Higher Education institutions have the availability of an ISSP roadmap. \\
\hline PSQ1 & $\begin{array}{c}\text { Higher Education institutions have the authority factor in planning strategic } \\
\text { planning. }\end{array}$ \\
\hline PSQ2 & $\begin{array}{l}\text { Planner (Planner) from ISSP in planning ISSP has an element of formality in } \\
\text { strategic planning, where the planning process is constructed and structured }\end{array}$ \\
\hline
\end{tabular}




\begin{tabular}{|c|c|}
\hline Code & Questionnaire \\
\hline & $\begin{array}{l}\text { with written, scheduled, and supported procedures by other documents, as } \\
\text { well as making documentation resulting from the planning process. }\end{array}$ \\
\hline PSQ3 & The ISSP Planner has all the strategic alternatives. \\
\hline PSQ4 & $\begin{array}{c}\text { The ISSP Planner has elements of efficiency and control of their planning } \\
\text { process. }\end{array}$ \\
\hline PSQ5 & $\begin{array}{l}\text { The ISSP planner has proof of the frequency and number of meetings in } \\
\text { determining resources directed in planning commitments. }\end{array}$ \\
\hline PSQ6 & $\begin{array}{l}\text { ISSP planners have documents about various individuals involved in strategic } \\
\text { planning. }\end{array}$ \\
\hline PSQ7 & $\begin{array}{c}\text { The ISSP planner has a document period of time considered in strategic } \\
\text { planning. }\end{array}$ \\
\hline PSQ8 & $\begin{array}{l}\text { ISSP Planner has a document about the existence of integration of BP-ISP } \\
\text { (Business Planning - Information Strategic Planning) in their planning. }\end{array}$ \\
\hline PSQ9 & The ISSP Planner has a Rational-Adaptation document in their planning. \\
\hline SDQ1 & $\begin{array}{l}\text { Higher Education institutions should have ISSP reliability /reliability } \\
\text { documents. }\end{array}$ \\
\hline SDQ2 & Higher Education institutions should have documents on responses to ISSP. \\
\hline SDQ3 & $\begin{array}{l}\text { Higher education institutions should have documents on collateral elements in } \\
\text { the ISSP. }\end{array}$ \\
\hline SDQ4 & Higher education institutions should have an empathy document on ISSP. \\
\hline SDQ5 & Higher Education institutions should have ISSP service recovery documents. \\
\hline SDQ6 & $\begin{array}{l}\text { Higher Education institutions should have documents about the ISSP service } \\
\text { delivery system. }\end{array}$ \\
\hline IFC1 & $\begin{array}{c}\text { Higher Education institutions should have documents on participation and } \\
\text { support from Top Management in ISSP. }\end{array}$ \\
\hline $\mathrm{IFC} 2$ & $\begin{array}{l}\text { Higher Education institutions should have documents on active } \\
\text { communication and knowledge sharing between the business and IT sectors } \\
\text { in the ISSP. }\end{array}$ \\
\hline IFC3 & $\begin{array}{l}\text { Higher education institutions should have documents of consideration from } \\
\text { the internal and external environment in the ISSP. }\end{array}$ \\
\hline IFC4 & $\begin{array}{l}\text { Higher Education institutions should have suitable resource allocation } \\
\text { documents to deal with ISSP implementation. }\end{array}$ \\
\hline IFC5 & $\begin{array}{c}\text { Higher Education institutions should have documents on organizational } \\
\text { learning within the ISSP. }\end{array}$ \\
\hline CUL1 & $\begin{array}{l}\text { ISSP should document the clarity of the influence of strategic direction in } \\
\text { leadership abilities. }\end{array}$ \\
\hline CUL2 & $\begin{array}{l}\text { ISSP should have relationship factors with organizations that have clarity } \\
\text { about strategic direction. }\end{array}$ \\
\hline CUL3 & $\begin{array}{l}\text { ISSP should have factors related to the organization's ability to maintain } \\
\text { contact with and responsive to change. }\end{array}$ \\
\hline CUL4 & $\begin{array}{c}\text { ISSP should have factors related to system alignment or adjustment in } \\
\text { organizations both horizontally and vertically. }\end{array}$ \\
\hline CUL5 & $\begin{array}{c}\text { ISSP should have factors related to the ability of humans and their teams } \\
\text { within the organization to work together. }\end{array}$ \\
\hline USE1 & The use of ISSP should have factors related to the number of uses of ISSP. \\
\hline USE2 & $\begin{array}{l}\text { The use of the ISSP should have a relationship with the frequency of using } \\
\text { ISSP. }\end{array}$ \\
\hline USE3 & The use of ISSP has factors related to compatibility in the use of ISSP. \\
\hline USE4 & The use of ISSP should have factors related to the naturalness of using ISSP. \\
\hline USE5 & The use of ISSP has factors associated with expanding the use of ISSP. \\
\hline USE6 & The use of ISSP should have factors related to the purpose of using ISSP. \\
\hline
\end{tabular}




\begin{tabular}{|c|c|}
\hline Code & Questionnaire \\
\hline SAT1 & $\begin{array}{l}\text { Higher Education institutions should have ISSP satisfaction documents that } \\
\text { can be assessed with the degree of support provided to ISSP users. }\end{array}$ \\
\hline SAT2 & $\begin{array}{l}\text { Higher Education institutions should have ISSP satisfaction documents that } \\
\text { can be assessed in terms of meeting the needs of ISSP users. }\end{array}$ \\
\hline SAT3 & $\begin{array}{c}\text { Higher Education institutions should have documents with important formats } \\
\text { in ISSP products. }\end{array}$ \\
\hline SAT4 & $\begin{array}{l}\text { Higher Education institutions should have documents about precise } \\
\text { information in ISSP. }\end{array}$ \\
\hline BEN & $\begin{array}{l}\text { ISSP has a net benefit that contains success factors such as good alignment } \\
\text { between planning and information systems, effectiveness, flexibility, } \\
\text { competitive advantage, increased performance, and capability. }\end{array}$ \\
\hline
\end{tabular}

\section{Research Methods}

The following in Figure 2 shows the stages of the study which consist of 5 stages of research. The first stage of $\mathrm{P} 1$ is the Assessment Planning, a stage that emphasizes the planning activities of the assessment of the questionnaire to be tested. The results of this stage are the assessment plan.

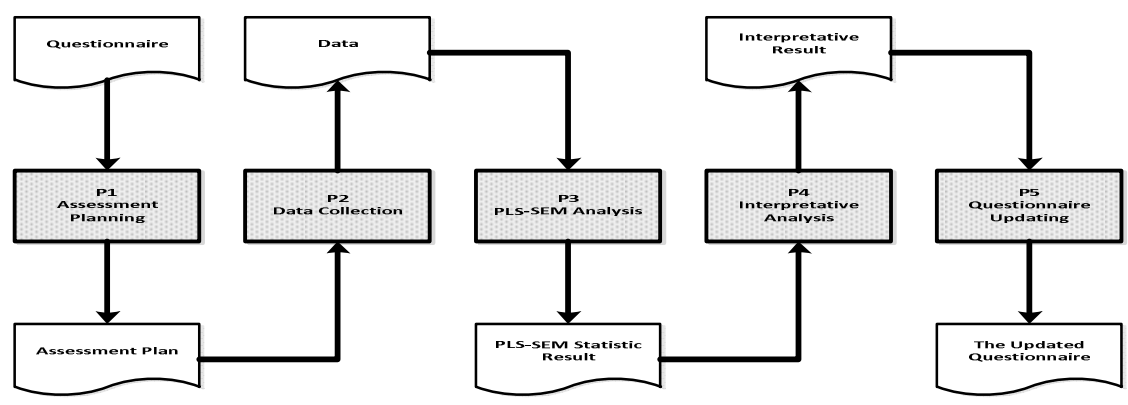

Figure 2. Stages of research

The second stage P2 emphasizes the collection of selected data based on the results of the assessment plan document. Data tested 41 questionnaire questions as many as 33 respondents. Data is collected using Google Form which is distributed to 80 respondents via the WhatsApp application. The respondents' data collected were then recorded with Microsoft Excel. Data from the second stage is then used as input in the third activity of P3, namely PLS-SEM analysis which produces statistical information about the test indicators, reliability and validity [45-49]. Stage P4 conducts interpretative analysis activities that produce important justifications related to testing the questionnaire[50-52]. Stage P5 is a questionnaire renewal activity to get a better questionnaire than the previous questionnaire[53]. 


\section{Results and Discussion}

\subsection{Information Related to Demography}

Respondent population characteristics related to filling in questionnaires are shown in table 3 , which consists of education, job level, ISSP Planner, The length of ownership of ISSP and Territory.

Table 3. Respondent's Demographics

\begin{tabular}{llcc}
\hline Characteristics & Group & $\begin{array}{c}\text { Number of } \\
\text { Respondents }\end{array}$ & Percentage \\
\hline Education & Ph.D. & 4 & 12 \\
& Master & 29 & 88 \\
& Bachelor & 0 & 0 \\
Job Level & Diploma & 0 & 0 \\
& Top Management & 10 & 30.30 \\
& Middle to low Management & 12 & 36.36 \\
ISSP Planner & Lecturer & 11 & 33.33 \\
& IT Staff & 0 & 0 \\
The length of & Yes & 11 & 33.33 \\
ownership of ISSP & No & 22 & 66.67 \\
& 2- years & 11 & 33.33 \\
Territory & 5- 10 years & 9 & 27.27 \\
& >10 years & 9 & 27.27 \\
& Jakarta & 4 & 12.12 \\
& Tangerang & 19 & 57.57 \\
& Yogyakarta & 1 & 3.03 \\
& Makassar & 1 & 3.03 \\
& Bandung & 2 & 6.06 \\
& Sumedang & 1 & 3.03 \\
& Kuningan & 3 & 9.09 \\
& Rokan Hulu & 5 & 15.15 \\
& & 1 & 3.03 \\
\hline
\end{tabular}

The demographic information of the respondents showed a positive side in the study even though there was little to be improved. Education from respondents is spread at the Masters and $\mathrm{Ph}$.D. levels, which will provide a level of confidence in the results of the study. This level of trust is also enlarged by the even distribution of the job level, which is about 30 percent for top management, middle to low management and lecturers. The population in this job level consists of ISSP Planner respondents which show 50 percent of the respondents who are not ISSP Planners, namely ISSP users, and ISSP Experts. Regarding the characteristics of the length of ownership of ISSP, it has been seen that around 70 percent indicate $>2$ years and the rest is still around 30 percent indicating $<2$ years. However, there is a slight weakness of the respondent population, namely Territory characteristics due to the limited distribution of questionnaires to areas that are not on target. Related to territory characteristics shows that the largest distribution of respondent populations still exists in two provinces, namely Jakarta, around 57 percent and West Java, around 27 percent, the rest spread to Yogyakarta, Riau and Makassar provinces.

Although there are weaknesses in the demographic information of respondents regarding the territory, information regarding the demographic characteristics of respondents may be 
consistent with the reality of the factors that influence the success of ISSP. On the basis of estimation aspects[54], where consistency can still be used to estimate research findings. It can be believed that consistency provides a representation of the real conditions of an object of research so that it can predict predictions regarding validity and reliability. So there is no doubt to recommend examining this research sample for research.

\subsection{PLS-SEM Analysis}

PLS-SEM analysis activities in this study produce statistical values to check the reliability of indicators, consistency of reliability, convergent validity, and discriminant validity[45-49].

Reliability testing of indicators using outer loading and cross loading is shown in table 4, which shows that the indicators of IFC1, PSQ1 and USE4 have values less than 0.7 (visible on shaded table cells), so that this indicator can be removed. However, because this research is an early stage of the measurement scale, these three indicators, which are between 0.5 and 0.6 , can be considered sufficient [55] and need not be eliminated.

Table 4. Reliability Indicator Testing Results

\begin{tabular}{|c|c|c|c|c|c|c|c|c|c|c|}
\hline \multirow{2}{*}{$\begin{array}{l}\text { Variabl } \\
\text { es }\end{array}$} & \multirow{2}{*}{$\begin{array}{l}\text { Indica } \\
\text { tors }\end{array}$} & \multirow{2}{*}{$\begin{array}{c}\text { Outer } \\
\text { Loadings }\end{array}$} & \multicolumn{8}{|c|}{ Cross Loadings } \\
\hline & & & BEN & CUL & IFC & IPQ & PSQ & SAT & SDQ & USE \\
\hline BEN & BEN & 1.000 & 1.000 & 0.598 & 0.644 & 0.503 & 0.597 & 0.561 & 0.537 & 0.677 \\
\hline \multirow[t]{5}{*}{ CUL } & CUL1 & 0.814 & 0.562 & 0.814 & 0.781 & 0.381 & 0.492 & 0.449 & 0.703 & 0.572 \\
\hline & CUL2 & 0.913 & 0.544 & 0.913 & 0.703 & 0.312 & 0.530 & 0.513 & 0.685 & 0.549 \\
\hline & CUL3 & 0.873 & 0.490 & 0.873 & 0.588 & 0.270 & 0.417 & 0.486 & 0.573 & 0.511 \\
\hline & CUL4 & 0.931 & 0.576 & 0.931 & 0.665 & 0.401 & 0.497 & 0.583 & 0.666 & 0.511 \\
\hline & CUL5 & 0.867 & 0.455 & 0.867 & 0.650 & 0.397 & 0.532 & 0.742 & 0.781 & 0.637 \\
\hline \multirow[t]{5}{*}{ IFC } & IFC1 & (x) & 0.325 & 0.423 & (x) & 0.343 & 0.445 & 0.339 & 0.599 & 0.300 \\
\hline & $\mathrm{IFC} 2$ & 0.887 & 0.467 & 0.643 & 0.887 & 0.454 & 0.518 & 0.619 & 0.611 & 0.628 \\
\hline & IFC3 & 0.791 & 0.607 & 0.555 & 0.791 & 0.365 & 0.421 & 0.531 & 0.593 & 0.604 \\
\hline & IFC4 & 0.855 & 0.551 & 0.585 & 0.855 & 0.362 & 0.384 & 0.380 & 0.594 & 0.487 \\
\hline & IFC5 & 0.889 & 0.612 & 0.837 & 0.889 & 0.429 & 0.614 & 0.702 & 0.762 & 0.724 \\
\hline \multirow[t]{5}{*}{ IPQ } & IPQ1 & 0.900 & 0.370 & 0.357 & 0.380 & 0.900 & 0.591 & 0.534 & 0.278 & 0.409 \\
\hline & IPQ2 & 0.837 & 0.406 & 0.338 & 0.394 & 0.837 & 0.562 & 0.495 & 0.332 & 0.440 \\
\hline & IPQ3 & 0.834 & 0.501 & 0.476 & 0.507 & 0.834 & 0.623 & 0.680 & 0.465 & 0.398 \\
\hline & IPQ4 & 0.784 & 0.520 & 0.170 & 0.403 & 0.784 & 0.610 & 0.448 & 0.284 & 0.354 \\
\hline & IPQ5 & 0.868 & 0.292 & 0.312 & 0.315 & 0.868 & 0.546 & 0.499 & 0.303 & 0.209 \\
\hline \multirow[t]{9}{*}{ PSQ } & PSQ1 & StS & 0.374 & 0.341 & 0.382 & 0.641 & "1) & 0.429 & 0.259 & 0.335 \\
\hline & PSQ2 & 0.705 & 0.608 & 0.539 & 0.600 & 0.599 & 0.705 & 0.497 & 0.579 & 0.562 \\
\hline & PSQ3 & 0.796 & 0.497 & 0.418 & 0.422 & 0.578 & 0.796 & 0.566 & 0.405 & 0.388 \\
\hline & PSQ4 & 0.738 & 0.455 & 0.512 & 0.425 & 0.568 & 0.738 & 0.661 & 0.546 & 0.542 \\
\hline & PSQ5 & 0.842 & 0.398 & 0.332 & 0.403 & 0.414 & 0.842 & 0.413 & 0.395 & 0.458 \\
\hline & PSQ6 & 0.777 & 0.381 & 0.451 & 0.567 & 0.551 & 0.777 & 0.528 & 0.493 & 0.628 \\
\hline & PSQ7 & 0.881 & 0.416 & 0.449 & 0.500 & 0.600 & 0.881 & 0.610 & 0.441 & 0.489 \\
\hline & PSQ8 & 0.793 & 0.380 & 0.359 & 0.293 & 0.458 & 0.793 & 0.455 & 0.324 & 0.366 \\
\hline & PSQ9 & 0.869 & 0.599 & 0.464 & 0.481 & 0.446 & 0.869 & 0.513 & 0.455 & 0.454 \\
\hline \multirow[t]{4}{*}{ SAT } & SAT1 & 0.878 & 0.616 & 0.616 & 0.626 & 0.560 & 0.691 & 0.878 & 0.662 & 0.610 \\
\hline & SAT2 & 0.910 & 0.483 & 0.642 & 0.574 & 0.619 & 0.612 & 0.910 & 0.587 & 0.612 \\
\hline & SAT3 & 0.918 & 0.490 & 0.582 & 0.549 & 0.567 & 0.620 & 0.918 & 0.662 & 0.661 \\
\hline & SAT4 & 0.726 & 0.311 & 0.314 & 0.516 & 0.451 & 0.375 & 0.726 & 0.472 & 0.655 \\
\hline
\end{tabular}




\begin{tabular}{|c|c|c|c|c|c|c|c|c|c|c|}
\hline \multirow{2}{*}{$\begin{array}{l}\text { Variabl } \\
\text { es }\end{array}$} & \multirow{2}{*}{$\begin{array}{l}\text { Indica } \\
\text { tors }\end{array}$} & \multirow{2}{*}{$\begin{array}{c}\text { Outer } \\
\text { Loadings }\end{array}$} & \multicolumn{8}{|c|}{ Cross Loadings } \\
\hline & & & BEN & CUL & IFC & IPQ & PSQ & SAT & SDQ & USE \\
\hline \multirow[t]{6}{*}{ SDQ } & SDQ1 & 0.785 & 0.424 & 0.772 & 0.773 & 0.586 & 0.464 & 0.657 & 0.785 & 0.569 \\
\hline & SDQ2 & 0.815 & 0.467 & 0.556 & 0.731 & 0.371 & 0.407 & 0.487 & 0.815 & 0.535 \\
\hline & SDQ3 & 0.923 & 0.616 & 0.719 & 0.720 & 0.321 & 0.533 & 0.635 & 0.923 & 0.554 \\
\hline & SDQ4 & 0.815 & 0.381 & 0.610 & 0.626 & 0.182 & 0.448 & 0.601 & 0.815 & 0.550 \\
\hline & SDQ5 & 0.823 & 0.303 & 0.598 & 0.449 & 0.206 & 0.500 & 0.547 & 0.823 & 0.375 \\
\hline & SDQ6 & 0.901 & 0.490 & 0.665 & 0.616 & 0.333 & 0.460 & 0.582 & 0.901 & 0.460 \\
\hline \multirow[t]{6}{*}{ USE } & USE1 & 0.875 & 0.488 & 0.505 & 0.535 & 0.330 & 0.460 & 0.558 & 0.397 & 0.875 \\
\hline & USE2 & 0.849 & 0.455 & 0.592 & 0.614 & 0.418 & 0.550 & 0.674 & 0.465 & 0.849 \\
\hline & USE3 & 0.920 & 0.703 & 0.620 & 0.653 & 0.396 & 0.558 & 0.720 & 0.610 & 0.920 \\
\hline & USE4 & SW & 0.261 & 0.322 & 0.327 & 0.265 & 0.373 & 0.342 & 0.444 & Wysts \\
\hline & USE5 & 0.829 & 0.649 & 0.521 & 0.592 & 0.277 & 0.501 & 0.613 & 0.513 & 0.829 \\
\hline & USE6 & 0.871 & 0.666 & 0.536 & 0.686 & 0.470 & 0.590 & 0.639 & 0.573 & 0.871 \\
\hline
\end{tabular}

Table 5 shows composite reliability and AVE data. Internal consistency reliability testing shows that composite reliability is above 0.7 in each construct, which means that all constructs can be relied on as a whole. Testing for convergent validity shows that the AVE value for each construct exceeds 0.5 . In table 6 shows that discriminant validity testing has sufficient value according to the Fornell-Larcker Criterion rule for all indicators so that no indicator is omitted.

Table 5. Construct Reliability and Validity

\begin{tabular}{lcc}
\hline & Composite Reliability & $\begin{array}{c}\text { AVE (Average Variance } \\
\text { Extracted) }\end{array}$ \\
\hline BEN & 1.000 & 1.000 \\
CUL & 0.945 & 0.775 \\
IFC & 0.904 & 0.657 \\
IPQ & 0.926 & 0.714 \\
PSQ & 0.932 & 0.607 \\
SAT & 0.919 & 0.742 \\
SDQ & 0.937 & 0.714 \\
USE & 0.928 & 0.685 \\
\hline
\end{tabular}

Table 6. Results of Fornell-Larcker Criterion

\begin{tabular}{lcccccccc}
\hline & BEN & CUL & IFC & IPQ & PSQ & SAT & SDQ & USE \\
\hline BEN & 1.000 & & & & & & & \\
CUL & 0.598 & 0.880 & & & & & & \\
IFC & 0.644 & 0.773 & 0.810 & & & & & \\
IPQ & 0.503 & 0.404 & 0.484 & 0.845 & & & & \\
PSQ & 0.597 & 0.564 & 0.595 & 0.698 & 0.779 & & & \\
SAT & 0.561 & 0.636 & 0.659 & 0.641 & 0.678 & 0.861 & & \\
SDQ & 0.537 & 0.781 & 0.781 & 0.403 & 0.573 & 0.697 & 0.845 & \\
USE & 0.677 & 0.635 & 0.704 & 0.438 & 0.617 & 0.732 & 0.606 & 0.828 \\
\hline
\end{tabular}

\subsection{Interpretative Analysis}

Table 7 shows the recommendations for each indicator based on PLS-SEM analysis and interpretative analysis. PLS-SEM analysis is based on the results of the statistics described 
previously which indicate that the approve for indicators that are in accordance with the model measurement rules relates to the reliability and validity of the indicators. There is another indication that is enough to be approved for indicators such as IFC1, PSQ1, and USE4 because the value is almost enough in the model measurement rules. The existence of interpretative analysis appears based on the results of the examination on PLS-SEM analysis. This analysis starts with an interpretive evaluation based on the response and cognition of the respondents. The results of this analysis indicate that all indicators indicate justification and recommend justify to be approved and updated the question. Specifically, recommendations, namely updated the question, are given for indicators such as IFC1, PSQ1, and USE4 because perhaps the current questions are not easily understood by respondents.

Table 7. Justifications and Recommendations

\begin{tabular}{|c|c|c|c|}
\hline $\begin{array}{c}\text { Indicat } \\
\text { ors }\end{array}$ & $\begin{array}{c}\text { PLS-SEM } \\
\text { Analysis }\end{array}$ & $\begin{array}{c}\text { Interpretative } \\
\text { Analysis }\end{array}$ & Recommendations \\
\hline BEN & Approved & Justified & Justify to be approved \\
\hline CUL1 & Approved & Justified & Justify to be approved \\
\hline CUL2 & Approved & Justified & Justify to be approved \\
\hline CUL3 & Approved & Justified & Justify to be approved \\
\hline CUL4 & Approved & Justified & Justify to be approved \\
\hline CUL5 & Approved & Justified & Justify to be approved \\
\hline IFC1 & $\begin{array}{c}\text { Enough to be } \\
\text { approved }\end{array}$ & Justified & Updated the question \\
\hline IFC2 & Approved & Justified & Justify to be approved \\
\hline IFC3 & Approved & Justified & Justify to be approved \\
\hline IFC4 & Approved & Justified & Justify to be approved \\
\hline IFC5 & Approved & Justified & Justify to be approved \\
\hline IPQ1 & Approved & Justified & Justify to be approved \\
\hline IPQ2 & Approved & Justified & Justify to be approved \\
\hline IPQ3 & Approved & Justified & Justify to be approved \\
\hline IPQ4 & Approved & Justified & Justify to be approved \\
\hline IPQ5 & Approved & Justified & Justify to be approved \\
\hline PSQ1 & $\begin{array}{c}\text { Enough to be } \\
\text { approved }\end{array}$ & Justified & Updated the question \\
\hline PSQ2 & Approved & Justified & Justify to be approved \\
\hline PSQ3 & Approved & Justified & Justify to be approved \\
\hline PSQ4 & Approved & Justified & Justify to be approved \\
\hline PSQ5 & Approved & Justified & Justify to be approved \\
\hline PSQ6 & Approved & Justified & Justify to be approved \\
\hline PSQ7 & Approved & Justified & Justify to be approved \\
\hline PSQ8 & Approved & Justified & Justify to be approved \\
\hline PSQ9 & Approved & Justified & Justify to be approved \\
\hline SAT1 & Approved & Justified & Justify to be approved \\
\hline SAT2 & Approved & Justified & Justify to be approved \\
\hline SAT3 & Approved & Justified & Justify to be approved \\
\hline SAT4 & Approved & Justified & Justify to be approved \\
\hline SDQ1 & Approved & Justified & Justify to be approved \\
\hline SDQ2 & Approved & Justified & Justify to be approved \\
\hline SDQ3 & Approved & Justified & Justify to be approved \\
\hline SDQ4 & Approved & Justified & Justify to be approved \\
\hline SDQ5 & Approved & Justified & Justify to be approved \\
\hline SDQ6 & Approved & Justified & Justify to be approved \\
\hline
\end{tabular}




\begin{tabular}{|c|c|c|c|}
\hline $\begin{array}{c}\text { Indicat } \\
\text { ors }\end{array}$ & $\begin{array}{c}\text { PLS-SEM } \\
\text { Analysis }\end{array}$ & $\begin{array}{c}\text { Interpretative } \\
\text { Analysis }\end{array}$ & Recommendations \\
\hline USE1 & Approved & Justified & Justify to be approved \\
\hline USE2 & Approved & Justified & Justify to be approved \\
\hline USE3 & Approved & Justified & Justify to be approved \\
\hline USE4 & $\begin{array}{c}\text { Enough to be } \\
\text { approved }\end{array}$ & Justified & Updated the question \\
\hline USE5 & Approved & Justified & Justify to be approved \\
\hline USE6 & Approved & Justified & Justify to be approved \\
\hline
\end{tabular}

\section{Conclusions}

Research related to the testing of questionnaires is currently likely still attractive to information system researchers because it is an important part of the development of survey instruments. In addition, variations in the testing of the questionnaire are still very limited, so that the presence of research may still be very expected regarding testing the questionnaire. Therefore it is still possible to continue to carry out this research.

The testing of the questionnaire in this study aims to examine the reliability and validity of the indicators in the ISSPBRM, by applying PLS-SEM analysis and sequential interpretative analysis to obtain recommendations related to the questionnaire. The test results show that there are 3 questions (related to indicators of IFC1, PSQ1, and USE4) of the 41 questions in the questionnaire that need to be updated.

The findings in this study cannot be generalized to other parties because the testing of the questionnaire is only limited to the object of the questionnaire and the sample examined in this study alone. This finding might provide practical input for researchers in similar work both in utilizing recommendations for updating questionnaires.

\section{Acknowledgments}

The researcher thanked Asia e University in Malaysia for providing an opportunity to develop this paper.

\section{References}

[1] A. Subiyakto, M. R. Juliansyah, M. C. Utami, and A. Susanto, "Combining the Statistical and Interpretative Analyses for Testing E-Commerce Customer Loyalty Questionnaire," in 2018 6th International Conference on Cyber and IT Service Management (CITSM), 2018, pp. 1-5.

[2] A. Subiyakto, R. Rosalina, M. C. Utami, N. Kumaladewi, and S. J. Putra, "The psychometric and interpretative analyses for assessing the end-user computing satisfaction questionnaire," in 2017 5th International Conference on Cyber and IT Service Management (CITSM), 2017, pp. 1-6.

[3] A. Subiyakto, A. R. Ahlan, M. Kartiwi, and H. T. Sukmana, "Influences of the input factors towards the success of an information system project," TELKOMNIKA (Telecommunication Computing Electronics and Control), vol. 13, pp. 686-693, 2015. 
[4] A. a. Subiyakto, A. R. Ahlan, S. J. Putra, and M. Kartiwi, "Validation of Information System Project Success Model," SAGE Open, vol. 5, p. 215824401558165, 2015.

[5] Earl, "Experiences Strategic Place in Information Systems Planning," MIS Quarterly, vol. 7, pp. 1-24, 1993.

[6] V. Arvidsson, J. Holmström, and K. Lyytinen, "Information systems use as strategy practice: A multi-dimensional view of strategic information system implementation and use," The Journal of Strategic Information Systems, vol. 23, pp. 45-61, 2014.

[7] F. K. Maria Kamariotou "StrategicInformationSystemsPlanning : SMEs Performance outcomes," 5th International Symposium and 27th National Conference on Operation Research Piraeus University of Appluied Sciences (Technological Education Institute of Piraeus) Aigaleo - Athens, June 9-11, 20162016.

[8] E. Osman, I. M. El Beltagi, and G. Hardaker, "The Impact of Leadership Orientation on Strategic Information System Planning Processes, with an Application to Libyan Organizations," Information Technology for Development, vol. 21, pp. 601-627, 2013.

[9] H. Harun and M. K. Hashim, "STRATEGIC INFORMATION SYSTEMS PLANNING: A REVIEW OF ITS CONCEPT, DEFINITIONS AND STAGES OF DEVELOPMENT," International Journal of Research In Science \& Engineering, vol. Volume: 3 Issue: 2 MarchApril 2017, 2017.

[10] Jacobson and Aaker, "The Strategic Role of Product Quality," Journal of Marketing, vol. 51, pp. 31-44, 1987.

[11] Lederer and Sethi, "Root Causes of Strategic Information Systems Implementation Planning Problems," Journal of Management Information Systems, vol. 9, pp. 25-45, 1992. [12] Lin, Wu, and Chang, "The critical factors impact on online customer satisfaction," Procedia Computer Science vol. 3, pp. 276-281, 2010.

[13] Lange, Mendling, and Recker, "A comprehensive EA benefit realization model - An exploratory study," IEEE-Hawaii International Conference on System Sciences, 2012.

[14] J. Ward, P. M. Griffiths, and P. Whitmore, Strategic planning for information systems vol. 3: Wiley Chichester, 2002.

[15] RHYNE, "CONTRASTING PLANNING SYSTEMS IN HIGH, MEDIUM AND LOW PERFORMANCE COMPANIES," Journal of Management Studies, vol. 24 : 4, 1987.

[16] Papke-Shields, Malhotra, and Grover, "Strategic Manufacturing Planning Systems and Their Linkage to Planning System Success," Decision Sciences, vol. 33, 2002.

[17] Craig, Dibrell, and Garrett, "Examining relationships among family influence, family culture, flexible planning systems, innovativeness and firm performance," Journal of Family Business Strategy, vol. 109, p. 10, 2013.

[18] K. Premkumar, "Assessing Strategic Information Systems Planning," Long Kange Planning, vol. 24 : 5, pp. 41-58, 1991.

[19] K. Premkumar "The evaluation of strategic information system planning " Information \& Management vol. 26, pp. 327-340 1994.

[20] T. Wang, "Factors Affecting Information Systems Planning Effectiveness : Organizational Contexts and Planning Systems Dimension," Information \& Management, vol. 40, pp. 287-303, 2001.

[21] C. Wolf and S. W. Floyd, "Strategic Planning Research: Toward a Theory-Driven Agenda," Journal of Management, vol. XX, pp. 1-35, 2013.

[22] S. Maharaj and I. Brown, "The impact of shared domain knowledge on strategic information systems planning and alignment," SA Journal of Information Management, vol. $17,2015$. 
[23] M. J. Culnan, "The Dimensions of Perceived Access i b i I it y to I $\mathrm{n} \mathrm{f}$ orm a $\mathrm{t}$ i on: Implications for the Delivery of Information Systems and Services," JOURNAL OF THE AMERICAN SOCIETY FOR INFORMATION SCIENCE, vol. 36, pp. 302-308, 1985.

[24] S. Pather and S. Usabuwera, "Implications of e-Service Quality Dimensions for the Information Systems Function," Proceedings of the 43rd Hawaii International Conference on System Sciences, 2010.

[25] S. Alamri, N. Almutiri, H. Ballahmar, and A. Zafar, "Strategic Information System Planning: A Case Study of a Service Delivery Company," Iarjset, vol. 3, pp. 78-84, 2016.

[26] A. Parasuraman, V. A. Zeithaml, and L. L. Berry, "Servqual: A multiple-item scale for measuring consumer perc," Journal of retailing, vol. 64, p. 12, 1988.

[27] J. Yang and Z. Pita, "RESEARCH INSTRUMENT FOR THE MEASUREMENT OF FACILITATORS FOR ENHANCING SISP SUCCESS AND DYNAMIC CAPABILITIES," PACIS 2014 Proceedings, 2014.

[28] J. Yang, M. Singh, Z. Pita, and I. Storey, "THE RELATIONSHIP BETWEEN STRATEGIC INFORMATION SYSTEMS PLANNING FACILITATORS AND THE SUCCESS OF SOUTH KOREAN ORGANISATIONS," PACIS 2015 Proceedings, 2015.

[29] Madon, "Computer-based information systems for development planning: the significance of cultural factors," Journal of Strategic Information Systems, vol. 1, 1992.

[30] S. Dellemijn, "The Relationship Between Information Systems Management and Organizational Culture," Communications of the IIMA vol. 11, pp. 21-34, 2011.

[31] Smit, Dellemijn, and Silvius, "The Relationship Between Organizational Culture, Information Systems Management And Change Readiness," PACIS 2012 Proceedings, p. $143,2012$.

[32] D. J. FLYNN and E. GOLENIEWSKA, "A survey of the use of strategic information systems planning approaches in UK organizations," Journal of Strategic Information Systems, vol. 2, 1993.

[33] M. Amami, G. Beghini, and M. L. Manna, "Use of project-management information system for planning information-systems development projects," International Journal of Project Management, vol. 11, 1994.

[34] Teo and Ang, "How useful are strategic plans for information systems?," BEHAVIOUR \& INFORMATION TECHNOLOGY, vol. 19, pp. 275 - 282, 2000.

[35] DeLone and McLean, "Information Systems Success Revisited," IEEE-Proceedings of the 35th Hawaii International Conference on System Sciences, 2002.

[36] Pe tter, DeLone, and McLean, "Measuring information systems success: models, dimensions, measures, and interrelationships," European Journal of Information Systems, vol. 17, pp. 236-263, 2008.

[37] A. Popovič, R. Hackney, P. S. Coelho, and J. Jaklič, "How information-sharing values influence the use of information systems: An investigation in the business intelligence systems context," The Journal of Strategic Information Systems, vol. 23, pp. 270-283, 2014. [38] B. G. Sudarsono and S. P. Lestari, "KAJIAN LITERATUR MODEL KONSEPTUAL KEBERHASILAN E-GOVERNMENT," KOMIK (Konferensi Nasional Teknologi Informasi dan Komputer), vol. 2, 2018.

[39] A. Subiyakto, "Assessing Information System Integration Using Combination of The Readiness and Success Models," Bulletin of Electrical Engineering and Informatics, vol. 7, pp. 400-410, 2018.

[40] A. Subiyakto, A. R. Ahlan, M. Kartiwi, S. J. Putra, and Y. Durachman, "The User Satisfaction Perspectives of the Information System Projects," Indonesian Journal of Electrical Engineering and Computer Science, vol. 4, pp. 215-223, 2016. 
[41] A. J. G. Silvius and J. Stoop, "The Relationship between the Process of Strategic Information Systems Planning and Its Success: An Explorative Study," 2013 46th Hawaii International Conference on System Sciences, pp. 4495-4501, 2013.

[42] C. G. M. N.F. Dohertya , A. Suhaimib, "The relative success of alternative approaches to strategic information systems planning: an empirical analysis," Journal of Strategic Information Systems vol. 8, pp. 263-283, 1999.

[43] A. D. OConnor, "Successful strategic information systems planning," J of lnfo Systems, vol. 3, 1993.

[44] T. Bechor, S. Neumann, M. Zviran, and C. Glezer, "A contingency model for estimating success of strategic information systems planning," Information \& Management, vol. 47, pp. 17-29, 2010.

[45] K. K.-K. Wong, "Partial least squares structural equation modeling (PLS-SEM) techniques using SmartPLS," Marketing Bulletin, vol. 24, pp. 1-32, 2013.

[46] W. Afthanorhan, "A comparison of partial least square structural equation modeling (PLS-SEM) and covariance based structural equation modeling (CB-SEM) for confirmatory factor analysis," International Journal of Engineering Science and Innovative Technology, vol. 2, pp. 198-205, 2013.

[47] J. F. Hair, C. M. Ringle, and M. Sarstedt, "PLS-SEM: Indeed a silver bullet," Journal of Marketing theory and Practice, vol. 19, pp. 139-152, 2011.

[48] V. Venkatesh, S. A. Brown, and H. Bala, "Bridging the qualitative-quantitative divide: Guidelines for conducting mixed methods research in information systems," MIS quarterly, pp. 21-54, 2013.

[49] N. Urbach and F. Ahlemann, "Structural equation modeling in information systems research using partial least squares," Journal of Information technology theory and application, vol. 11, pp. 5-40, 2010.

[50] A. Subiyakto, A. R. Ahlan, M. Kartiwi, and H. T. Sukmana, "Measurement of information system project success based on perceptions of the internal stakeholders," International Journal of Electrical and Computer Engineering (IJECE), vol. 5, pp. 271-279, 2015.

[51]N. A. Abdullah, D. Nishioka, and Y. Murayama, "Questionnaire Testing: Identifying Twitter User's Information Sharing Behavior during Disasters," Journal of Information Processing, vol. 24, pp. 20-28, 2016.

[52] Q. Shahab, J. Terken, and B. Eggen, "Development of a questionnaire for identifying driver's personal values in driving," in Proceedings of the 5th International Conference on Automotive User Interfaces and Interactive Vehicular Applications, 2013, pp. 202-208.

[53] A. Subiyakto, A. R. Ahlan, M. Kartiwi, and S. J. Putra, "Measurement of the information system project success of the higher education institutions in Indonesia: a pilot study," Int. J. Business Information Systems, vol. 23, 2016.

[54] J. Christopher, C. B. Schertzer, and S. M. Schertzer, "Accounting faculty internships: A descriptive study," SAGE Open, vol. 3, p. $2158244013490701,2013$.

[55] W. W. Chin, "The partial least squares approach to structural equation modeling," Modern methods for business research, vol. 295, pp. 295-336, 1998. 